(2) Open Access Full Text Article

\title{
Improving the medical student experience using electronic timetabling
}

This article was published in the following Dove Press journal:

Advances in Medical Education and Practice

5 July 2014

Number of times this article has been viewed

\section{Sayinthen Vivekanantham \\ Rahul Prashanth Ravindran \\ Imperial College School of Medicine, Imperial College London, London, UK}

Correspondence: Sayinthen

Vivekanantham

Imperial College School of Medicine,

Imperial College London, London,

SW7 2AZ, UK

Tel +44207589 5III

Email sayinthen.vivekanantham@gmail.com

\section{Dear editor}

Technology within health care delivery is improving at an unprecedented rate. ${ }^{1}$ Medical students demonstrate a preference towards mobile learning ${ }^{2}$ and familiarity with technology is essential to medical practice. ${ }^{1}$ We believe electronic timetables are an underutilized technology that can be embraced by institutions delivering medical education.

We have implemented a university-wide electronic calendar to keep students informed of extra-curricular educational events. In a poll conducted on a cohort of 197 clinical medical students, $95 \%$ are either currently using, or intend to use, the calendar. Moreover, we found that the average student spends 12 hours a year transferring their curriculum timetable from the current paper-based format to an electronic format. This means that 3,600 hours would be used on this activity across an average year group of 300 students; this time could be saved by one faculty-member distributing timetables in an electric format.

Eighty percent (102 of 127) of students who responded believed an electronic timetable would improve their time management, and 59\% (64 of 109) agreed that it would improve their review of course material. Ninety-seven percent (150 of 154) of students said they would use an electronic timetable as a primary timetable, with $99 \%$ (152 of 154) having an appropriate portable device for it. Lastly, 65\% (89 of 136) reported that an electronic timetable would improve their punctuality and attendance to timetabled teaching.

Electronic calendars may be of greater benefit to clinical students, as teaching opportunities tend to be less structured and more diverse compared to preclinical training. ${ }^{3,4}$ Perhaps a barrier to the uptake of electronic calendars is concern from medical schools that not all students have a compatible device; however, our results show that appropriate personal devices are prevalent amongst medical students. Moreover, electronic timetables can be printed out to accommodate those without appropriate devices.

Medical students use electronic calendars for over $50 \%$ of their learning activities through self, rather than institutional, initiatives. ${ }^{3}$ There are numerous benefits for institutions to introduce electronic timetabling, including easy identification of timetable clashes, as well as informing individuals of time or location changes through amendments of a central timetable that synchronizes across devices. Financial savings thanks to electronic systems have been realized in other settings, ${ }^{5}$ and adoption 
of electronic timetables would save the printing and staffing costs associated with conventional paper timetables. We hope that electronic timetables will not only improve efficiency and reduce costs for institutions and students alike, but also be a catalyst for the use of technology in medical education.

\section{Disclosure}

Sayinthen Vivekanantham is founding Director and Rahul Ravindran is a Trustee of Global Medical Education Trust (GMET), a recently established charity that aims to improve the quality of medical education and learning within health care.

\section{References}

1. Abraham S. Technological trends in health care: electronic health record. Health Care Manag (Frederick). 2010;29(4):318-323.

2. Gormley GJ, Collins K, Boohan M, Bickle IC, Stevenson M. Is there a place for e-learning in clinical skills? A survey of undergraduate medical students' experiences and attitudes. Med Teach. 2009;31(1):e6-e12.

3. Han H, Nelson E, Wetter N. Medical students' online learning technology needs. Clin Teach. 2014;11(1):15-19.

4. Smith P, Morrison J. Clinical clerkships: students can structure their own learning. Med Educ. 2006;40(9):884-892.

5. Hillestad R, Bigelow J, Bower A, et al. Can electronic medical record systems transform health care? Potential health benefits, savings, and costs. Health Aff (Millwood). 2005;24(5):1103-1117.

\section{Publish your work in this journal}

Advances in Medical Education and Practice is an international, peerreviewed, open access journal that aims to present and publish research on Medical Education covering medical, dental, nursing and allied health care professional education. The journal covers undergraduate education, postgraduate training and continuing medical education including emerging trends and innovative models linking education, research, and health care services. The manuscript management system is completely online and includes a very quick and fair peer-review system. Visit http://www.dovepress.com/testimonials.php to read real quotes from published authors.

Submit your manuscript here: http://www.dovepress.com/advances-in-medical-education-and-practice-journal 